\title{
Adjuvants for Coronavirus Vaccines
}

\section{OPEN ACCESS}

Edited by:

Katie Ewer,

University of Oxford, United Kingdom

Reviewed by:

Anke Huckriede,

University Medical Center Groningen,

Netherlands

Andrew Ishizuka,

National Institutes of Health $(\mathrm{NIH})$,

United States

Tamiru Alkie,

Wilfrid Laurier University, Canada

*Correspondence:

Bingbing Sun

bingbingsun@dlut.edu.cn

Hao Zeng

zeng1109@163.com

${ }^{\dagger}$ Present Address:

Li Shi,

Immune Path Biotechnology

Co., Ltd., Suzhou, China

Specialty section:

This article was submitted to

Vaccines and Molecular

Therapeutics,

a section of the journal

Frontiers in Immunology

Received: 31 July 2020

Accepted: 14 October 2020

Published: 06 November 2020

Citation:

Liang Z, Zhu H, Wang $X$, Jing B, Li Z, Xia $X$, Sun $H$, Yang $Y$, Zhang $W$, Shi $L$, Zeng $H$ and Sun $B$ (2020) Adjuvants

for Coronavirus Vaccines.

Front. Immunol. 11:589833.

doi: 10.3389/fimmu.2020.589833

\author{
Zhihui Liang ${ }^{1,2}$, Haoru Zhu ${ }^{1,2}$, Xin Wang ${ }^{2}$, Bo Jing ${ }^{2}$, Zifan $L^{2}{ }^{2}$, Xinyu Xia ${ }^{1,2}$, Hongwu Sun ${ }^{3}$, \\ Yun Yang ${ }^{3}$, Weiting Zhang ${ }^{4}$, Li Shi ${ }^{5+}$, Hao Zeng ${ }^{3 *}$ and Bingbing Sun ${ }^{1,2^{\star}}$ \\ 1 State Key Laboratory of Fine Chemicals, Dalian University of Technology, Dalian, China, ${ }^{2}$ School of Chemical Engineering, \\ Dalian University of Technology, Dalian, China, ${ }^{3}$ National Engineering Research Center of Immunological Products, \\ Department of Microbiology and Biochemical Pharmacy, College of Pharmacy and Laboratory Medicine, Third Military \\ Medical University, Chongqing, China, ${ }^{4}$ NCPC Genetech Biotechnology Co., Ltd., Shijiazhuang, China, ${ }^{5}$ Basic Research \\ Department, Shanghai Zerun Biotechnology Co., Ltd., Shanghai, China
}

Vaccine development utilizing various platforms is one of the strategies that has been proposed to address the coronavirus disease 2019 (COVID-19) pandemic. Adjuvants are critical components of both subunit and certain inactivated vaccines because they induce specific immune responses that are more robust and long-lasting. A review of the history of coronavirus vaccine development demonstrates that only a few adjuvants, including aluminum salts, emulsions, and TLR agonists, have been formulated for the severe acute respiratory syndrome-associated coronavirus (SARS-CoV), Middle East respiratory syndrome-related coronavirus (MERS-CoV), and currently the SARS-CoV-2 vaccines in experimental and pre-clinical studies. However, there is still a lack of evidence regarding the effects of the adjuvants tested in coronavirus vaccines. This paper presents an overview of adjuvants that have been formulated in reported coronavirus vaccine studies, which should assist with the design and selection of adjuvants with optimal efficacy and safety profiles for COVID-19 vaccines.

Keywords: coronavirus disease 2019 , SARS-CoV-2, adjuvant, coronavirus vaccine, aluminum salt

\section{INTRODUCTION}

Coronaviruses (CoVs) are single-stranded RNA viruses characterized by club-like spikes that can potentially cause severe respiratory disease in humans $(1,2)$. The outbreak of severe acute respiratory syndrome (SARS) caused by the SARS-CoV resulted in more than 8000 confirmed infections, with an overall case fatality rate of $10 \%$ in 2002 (3). The Middle East respiratory syndrome (MERS)-CoV continues to cause deaths with increasing geographical distribution and a $34.4 \%$ case fatality rate, according to the World Health Organization (WHO) (4). Most recently, the coronavirus disease 2019 (COVID-19) caused by SARS-CoV-2 has spread globally, with over 33 million confirmed cases as of October 2020 (5). Considering the challenges to global health systems and the far-reaching consequences on the world economy, there is an urgent need to develop effective and safe vaccines that can be quickly deployed on a global scale $(2,6)$.

Vaccine candidates are currently under development using different platforms, such as inactivated vaccines, recombinant protein vaccines, live-attenuated vaccines, viral vector (adenovirus) vaccines, DNA vaccines, and mRNA vaccines $(2,6,7)$. Adenovirus-vector could induce potent immunological responses due to the presence of viral proteins and stimulation of innate immunity sensors, e.g., toll-like receptors (8). Nucleic-acid vaccines, e.g., DNA and mRNA vaccines, encode the virus's spike protein, intrinsically could engage innate immunity that instructs 
induction of immune protection (9). However, these platforms haven't been used in licensed human vaccines before. In other platforms, subunit or inactivated antigens were used, but these antigens lack the immunological profiles that mediate the enhanced adaptive immunity. Thus, in these $\mathrm{CoV}$ vaccines, they require the addition of adjuvants for directing the types and magnitude of immune responses (10). In previously reported exploratory and pre-clinical $\mathrm{CoV}$ vaccine studies, adjuvants such as aluminum salts, emulsions, and toll-like receptor (TLR) agonists, have been used in vaccine formulations for studies with various animal models (Table 1). The adjuvants AS03, MF59, and CpG 1018 have already been used in licensed vaccines (28) and have been committed by GlaxoSmithKline, Seqirus, and Dynavax to be available for COVID-19 vaccine development (29). When combined with subunit and specific inactivated antigens $(30,31)$, adjuvants with various characteristics elicit distinctive immunological profiles with regard to the direction, duration, and strength of immune responses. Thus far, there are at least 40 candidate vaccines in clinical trials and 149 vaccines in preclinical evaluation, of which 67 subunit and 15 inactivated COVID-19 vaccines have being developed (32). Among these adjuvants, alum have been formulated with $S$ protein or RBD to induce neutralizing antibody production $(17,18)$, which has suggested to be associated with protection against SARS-CoV-2 $(15,16,24)$. However, alum lacks the capability to promote the activation of $\mathrm{CD}^{+}$and $\mathrm{CD} 8^{+} \mathrm{T}$ cell responses, which has been demonstrated to coordinate with the antibody responses to provide protective immunity against the SARS-CoV-2 (33). Other adjuvants, e.g., emulsion adjuvants and TLR agonists, which have been shown to induce both humoral and cellular immune responses could be more favorable. However, no phase III clinical trial results of COVID-19 vaccines are published so far, thus, there is no direct evidence to indicate which type of immune response induced by vaccine plays a more critical protective role in SARS-CoV-2 infection. Knowing these uncertainties, an overview of previous $\mathrm{CoV}$ vaccine studies using different adjuvants would be indispensable for the design and development of a COVID-19 vaccine.

The SARS-CoV-2 is a novel strain of the coronavirus, and very little is known about its epidemiology and pathogenesis. Therefore, extreme cautions should be taken when considering vaccine formulations that can achieve the desired efficacy and safety profiles. The selection of adjuvants should consider the magnitude, affinity, isotype, and durability of antibodies that are critical for coronavirus vaccine developments (34). It should be noted that low antibody production may lead to antibodydependent enhancement (ADE) manifested by severe liver damage and enhanced infection (35), while high affinity neutralizing antibodies could help to avoid ADE. Additionally, the proper application of adjuvants also depends on the choice of antigens. The full-length $\mathrm{S}$ protein is more likely to trigger ADE due to mild antibody production (36). In comparison, the $\mathrm{N}$ protein is generally highly conserved, and it is associated with the ability to induce cytotoxic T lymphocytes (CTL). However, N protein could potentiate pro-inflammatory cytokine production and lead to severe lung pathology (37). In addition, previous study on respiratory syncytial virus (RSV) vaccine also indicated that immunization with whole inactivated virus could lead to vaccine-associated enhanced respiratory disease (VAERD), manifested by allergic inflammation and Th2 type immune responses (38). Altogether, these studies suggest that vaccines formulated with various antigen isotypes may require proper adjuvant selection to achieve the desired immune protection. In this paper, we reviewed adjuvants that have already been incorporated in the coronavirus vaccines under exploratory and pre-clinical investigations. By reviewing the vaccine formulations and the types of immune responses that were induced, we provide information that will enable proper adjuvant selection for COVID-19 vaccines to facilitate rapid vaccine delivery.

\section{ALUMINUM SALT-BASED ADJUVANTS}

Aluminum salt-based adjuvants (alum) were the first adjuvants used in licensed human vaccines. They are still the most widely used because of their wide-spectrum ability to strengthen immune responses and their excellent track record of safety (39-41). In limited coronavirus vaccine studies, it has been suggested that neutralizing antibody against the spike protein might be mechanistically correlated with immune protection (42). When alum was formulated with S protein or receptorbinding domain (RBD), it significantly enhanced humoral immune responses. This was demonstrated by higher titers of serum $\operatorname{IgG}_{1}$, increased high affinity viral neutralizing antibodies, and the generation of long-lasting memory B cells in mice (13, 17-19). Additionally, Alum was formulated with the inactivated and VLP vaccines containing $\mathrm{E}, \mathrm{M}$, and $\mathrm{N}$ proteins $(11,12,14)$ (Table 1) that showed enhanced $\mathrm{IgG}_{1}$ and neutralizing antibody titers (14) and prolonged durability (12). Studies also demonstrated that alum adjuvant plays an essential role in the dose-sparing of $\mathrm{CoV}$ vaccines. In a SARS $\mathrm{S}$ protein subunit vaccine, the alum-adjuvanted $S$ protein $(1 \mu \mathrm{g})$ group showed neutralizing antibody titers similar to or higher than the nonadjuvanted $\mathrm{S}$ protein $(50 \mu \mathrm{g})$ group. The alum-adjuvanted $\mathrm{S}$ protein $(5 \mu \mathrm{g})$ group showed a geometric mean titer (GMT) twice as high as the non-adjuvanted $S$ protein $(50 \mu \mathrm{g})$ group (20). It should also be noted that different types of alum were selected in the studies, including Alhydrogel, which is chemically crystalline aluminum oxyhydroxide (43), aluminum hydroxide (11), aluminum phosphate (22), and Imject ${ }^{\mathrm{TM}}$ Alum (23), which is a mixture of aluminum hydroxide and magnesium hydroxide. Even though there is no specific description regarding the aluminum hydroxide in reported literature $(11,18,21)$, it can also be referred to Aluminum oxyhydroxide (44). However, these studies lacked systematic comparisons with regards to their adjuvanticity and how various alum-based adjuvants differed in their ability to induce neutralizing antibodies.

It is worth noting that inactivated SARS-CoV or S proteinbased vaccines are associated with Th2-type immunopathology, which is characterized by an increase in eosinophils and inflammatory infiltrates $(14,30,37,45)$. Moreover, the 
TABLE 1 | Alum based adjuvants used in the coronavirus vaccine formulations under exploratory and pre-clinical investigations.

\begin{tabular}{|c|c|c|c|c|c|c|c|c|c|c|c|c|c|c|c|c|c|}
\hline \multirow{2}{*}{$\begin{array}{l}\text { Adjuvant } \\
\text { Type }\end{array}$} & \multirow[t]{2}{*}{ Platform } & \multirow[t]{2}{*}{ Adjuvant } & \multirow[t]{2}{*}{ Antigen } & \multirow[t]{2}{*}{ Antigen Dose } & \multicolumn{8}{|c|}{ Immunological response } & \multirow[t]{2}{*}{ Route } & \multirow{2}{*}{$\begin{array}{l}\text { Immunization } \\
\text { Schedule }\end{array}$} & \multirow[t]{2}{*}{ Safety } & \multirow[t]{2}{*}{ Animal model } & \multirow[t]{2}{*}{ Ref. } \\
\hline & & & & & Nab & $\lg _{1}$ & $\operatorname{lgG}_{2 a}$ & $\lg A$ & $\begin{array}{c}\text { Th1 } \\
\text { cytokines }\end{array}$ & $\begin{array}{c}\text { Th2 } \\
\text { cytokines }\end{array}$ & $\begin{array}{l}\text { Th17 } \\
\text { Cytokines }\end{array}$ & $\begin{array}{l}\mathrm{CD8}^{+} \\
\mathrm{T} \text { cell } \\
\text { response }\end{array}$ & & & & & \\
\hline \multirow[t]{18}{*}{$\begin{array}{l}\text { Alum } \\
\text { based } \\
\text { adjuvants }\end{array}$} & $\begin{array}{l}\text { Inactivated } \\
\text { vaccines }\end{array}$ & $\begin{array}{l}\text { Aluminum } \\
\text { hydroxide }\end{array}$ & $\begin{array}{l}\text { Doubly inactivated } \\
\text { (formalin and UV) } \\
\text { whole SARS virus }\end{array}$ & $\begin{array}{l}0.125 / 0.25 / 0.5 / 1 \\
\mu \mathrm{g}\end{array}$ & v & N/A & N/A & N/A & N/A & N/A & N/A & N/A & i.m. & 2 & $\begin{array}{c}\text { Pulmonary } \\
\text { immunopathology }\end{array}$ & $\begin{array}{l}\text { BALB/c or } \mathrm{C} 57 \mathrm{BL} / 6 \\
\text { mice }\end{array}$ & (11) \\
\hline & $\begin{array}{l}\text { Inactivated } \\
\text { vaccines }\end{array}$ & $\begin{array}{l}\text { Aluminum } \\
\text { hydroxide }\end{array}$ & $\begin{array}{l}\text { Purified beta } \\
\text { propiolactone } \\
\text { inactivated whole } \\
\text { SARS virus }\end{array}$ & $2 \mu \mathrm{g}$ & $\checkmark$ & N/A & N/A & N/A & N/A & N/A & N/A & $\mathrm{N} / \mathrm{A}$ & i.m. & 2 & N/A & $\begin{array}{l}\text { BALB/c or C57BL/6 } \\
\text { mice }\end{array}$ & (11) \\
\hline & $\begin{array}{l}\text { Inactivated } \\
\text { vaccines }\end{array}$ & $\begin{array}{l}\text { Aluminum } \\
\text { hydroxide gel }\end{array}$ & $\begin{array}{l}\text { UV-inactivated } \\
\text { purified SARS-CoV }\end{array}$ & $10 \mu \mathrm{g}$ & $\checkmark$ & $\checkmark$ & $x$ & $x$ & $\checkmark$ & 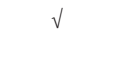 & N/A & N/A & s.c. & 2 & N/A & BALB/c mice & (12) \\
\hline & $\begin{array}{l}\text { Inactivated } \\
\text { vaccines }\end{array}$ & $\begin{array}{l}\text { Aluminum } \\
\text { hydroxide }\end{array}$ & $\begin{array}{l}\text { SARS-CoV } \\
\text { (formaldehyde and } \\
\text { U.V. inactivation) }\end{array}$ & $0.3 \sim 1 \mu \mathrm{g}$ & $\sqrt{ }$ & N/A & N/A & N/A & $\sqrt{ }$ & $\checkmark$ & N/A & N/A & s.c. & 2 & N/A & $\begin{array}{l}\mathrm{CD1} \\
\text { mice }\end{array}$ & (13) \\
\hline & $\begin{array}{l}\text { Inactivated } \\
\text { vaccines }\end{array}$ & Alum & $\begin{array}{l}\text { Double-inactivated } \\
\text { SARS-CoV (DIV) }\end{array}$ & $0.2 \mu \mathrm{g}$ & $\checkmark$ & $\checkmark$ & $x$ & N/A & $x$ & $\checkmark$ & $\mathrm{N} / \mathrm{A}$ & N/A & $\begin{array}{l}\text { Footpad } \\
\text { injection }\end{array}$ & 2 & $\begin{array}{l}\text { Lung } \\
\text { immunopathology }\end{array}$ & BALB/c AnNHsd mice & (14) \\
\hline & $\begin{array}{l}\text { Inactivated } \\
\text { vaccines }\end{array}$ & $\begin{array}{l}\text { Aluminum } \\
\text { hydroxide }\end{array}$ & SARS-CoV-2 & $\begin{array}{l}\text { Mice/Rats:1.5/3/6 } \mu \mathrm{g} ; \\
\text { Monkeys:1.5/6 } \mu \mathrm{g}\end{array}$ & v & N/A & N/A & N/A & $x$ & $x$ & N/A & N/A & i.m.li.p. & $\begin{array}{l}\text { Mice/Rats:2; } \\
\text { Monkeys:3 }\end{array}$ & $x$ & $\begin{array}{l}\text { BALB/c mice; Wistar } \\
\text { rats; Rhesus macaques }\end{array}$ & (15) \\
\hline & $\begin{array}{l}\text { Inactivated } \\
\text { vaccines }\end{array}$ & $\begin{array}{l}\text { Aluminum } \\
\text { hydroxide }\end{array}$ & SARS-CoV-2 & $\begin{array}{l}2 / 4 / 8 \\
(\mu \mathrm{g} / \mathrm{dose})\end{array}$ & $\checkmark$ & $\mathrm{N} / \mathrm{A}$ & N/A & N/A & N/A & N/A & N/A & N/A & i.p./i.m & $1 / 2 / 3$ & $\begin{array}{l}\text { No acute toxicity/No } \\
\text { Systemic anaphyla/ } \\
\text { No long-term toxicity }\end{array}$ & $\begin{array}{l}\text { Rats; Mice guinea pigs; } \\
\text { Rabbits, Cynomol-gus } \\
\text { monkeys; Rhesus } \\
\text { macaques }\end{array}$ & (16) \\
\hline & $\begin{array}{l}\text { Subunit } \\
\text { vaccines }\end{array}$ & Alhydrogel & SARS S protein & $3 \mu \mathrm{g}$ & v & N/A & N/A & N/A & N/A & N/A & N/A & N/A & i.m. & 2 & N/A & BALB/c mice & (17) \\
\hline & $\begin{array}{l}\text { Subunit } \\
\text { vaccines }\end{array}$ & Alhydrogel & MERS S protein & 1/3/10 $\mu \mathrm{g}$ & $\checkmark$ & N/A & N/A & $\mathrm{N} / \mathrm{A}$ & N/A & N/A & N/A & N/A & i.m. & 2 & N/A & $\mathrm{BALB} / \mathrm{c}$ mice & (17) \\
\hline & $\begin{array}{l}\text { Subunit } \\
\text { vaccines }\end{array}$ & $\begin{array}{l}\text { Aluminum } \\
\text { hydroxide }\end{array}$ & $\begin{array}{l}\text { MERS-CoV S } \\
\text { rRBD Protein }\end{array}$ & $10 \mu \mathrm{g}$ & $\sqrt{ }$ & $\checkmark$ & $v$ & N/A & $x$ & $\checkmark$ & N/A & N/A & i.m. & 3 & N/A & BALB/c mice & (18) \\
\hline & $\begin{array}{l}\text { Subunit } \\
\text { vaccines }\end{array}$ & Alhydrogel & $\begin{array}{l}\text { SARS-CoV S318- } \\
510 \text { fragment }\end{array}$ & $8 \mu \mathrm{g}$ & $\checkmark$ & $\checkmark$ & $x$ & N/A & $x$ & N/A & $N / A$ & N/A & s.c. & 2 & N/A & 129S6/SvEv mice & (19) \\
\hline & $\begin{array}{l}\text { Subunit } \\
\text { vaccines }\end{array}$ & Alhydrogel & $\begin{array}{l}\text { Ectodomain of } \\
\text { SARS-CoV S } \\
\text { glycoprotein } \\
\text { ( } \Delta \text { TMS) }\end{array}$ & $1 / / 5 \mu \mathrm{g}$ & $\checkmark$ & N/A & N/A & N/A & N/A & N/A & N/A & N/A & i.m. & 1 & N/A & CD1 mice & (20) \\
\hline & $\begin{array}{l}\text { Subunit } \\
\text { vaccines }\end{array}$ & $\begin{array}{l}\text { Aluminum } \\
\text { hydroxide }\end{array}$ & $\begin{array}{l}\text { S glycoprotein of } \\
\text { SARS-CoV }\end{array}$ & $0.25 / 0.5 / 1 / 2 \mu \mathrm{g}$ & $\checkmark$ & N/A & N/A & N/A & N/A & N/A & $\mathrm{N} / \mathrm{A}$ & N/A & i.m. & 2 & $\mathrm{~N} / \mathrm{A}$ & $\begin{array}{l}\text { BALB/c or } \mathrm{C} 57 \mathrm{BL} / 6 \\
\text { mice }\end{array}$ & (11) \\
\hline & $\begin{array}{l}\text { Subunit } \\
\text { vaccines }\end{array}$ & $\begin{array}{l}\text { Aluminum } \\
\text { hydroxide }\end{array}$ & $\begin{array}{l}\text { MERS-CoV rRBD } \\
\text { protein S367-606 }\end{array}$ & $\begin{array}{l}100 / 50 \mu \mathrm{g} \text { (primed) } \\
+50 / 25 \mu \mathrm{g} \\
\text { (boosted) }\end{array}$ & 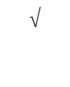 & N/A & N/A & $\mathrm{N} / \mathrm{A}$ & N/A & N/A & $\mathrm{N} / \mathrm{A}$ & $\mathrm{N} / \mathrm{A}$ & i.m. & 3 & N/A & Monkeys & (21) \\
\hline & $\begin{array}{l}\text { Subunit } \\
\text { vaccines }\end{array}$ & $\begin{array}{l}\text { Aluminum } \\
\text { phosphate }\end{array}$ & $\begin{array}{l}\text { MERS-CoV S1 } \\
\text { protein }\end{array}$ & $10 \mu \mathrm{g}$ & $\checkmark$ & $\mathrm{N} / \mathrm{A}$ & N/A & N/A & N/A & N/A & N/A & N/A & i.m. & 2 & N/A & BALB/c mice & (22) \\
\hline & $\begin{array}{l}\text { Subunit } \\
\text { vaccines }\end{array}$ & $\begin{array}{l}\text { Imject }^{\mathrm{TM}} \\
\text { Alum }\end{array}$ & $\begin{array}{l}\text { MERS-CoV RBD- } \\
\text { dimer }\end{array}$ & $10 \mu \mathrm{g}$ & $\checkmark$ & $\mathrm{N} / \mathrm{A}$ & N/A & $\mathrm{N} / \mathrm{A}$ & $x$ & $x$ & $N / A$ & N/A & i.m. & 3 & N/A & BALB/c mice & (23) \\
\hline & $\begin{array}{l}\text { Subunit } \\
\text { vaccines }\end{array}$ & $\begin{array}{l}\text { Aluminum } \\
\text { hydroxide gel }\end{array}$ & $\begin{array}{l}\text { RBD of SARS-CoV- } \\
2 \text { spike protein }\end{array}$ & $0.1-20 \mu \mathrm{g}$ & $\checkmark$ & N/A & N/A & N/A & N/A & N/A & N/A & N/A & i.m & $1 / 2 / 3$ & Safe & $\begin{array}{l}\text { BALB/c and C57BL } \\
6 \text { 6mice; Rabbits;Non- } \\
\text { human primates (Macaca } \\
\text { mulatta) }\end{array}$ & (24) \\
\hline & $\begin{array}{l}\text { VLP } \\
\text { vaccines }\end{array}$ & $\begin{array}{l}\text { Aluminum } \\
\text { hydroxide }\end{array}$ & $\begin{array}{l}\text { SARS-CoV S } \\
\text { glycoprotein and E, } \\
M \text {, and N proteins }\end{array}$ & $2 \mu \mathrm{g}$ & $x$ & $\mathrm{~N} / \mathrm{A}$ & N/A & N/A & N/A & N/A & N/A & N/A & i.m. & 2 & $\mathrm{~N} / \mathrm{A}$ & $\begin{array}{l}\text { BALB/c or C57BL/6 } \\
\text { mice }\end{array}$ & (11) \\
\hline
\end{tabular}

Annotation:

S protein is the spike glycoprotein of coronavirus and a main target for neutralizing antibodies (25):

RBD is the receptor-binding domain (RBD) of S protein, which could directly interact with the angiotensin-converting enzyme 2 (ACE2) receptor on host cells (25);

$\boldsymbol{N}$ protein is the highly conserved nucleocapsid protein of coronavirus and regulates RNA replication and transcription (26);

M protein (membrane protein) is the most abundant protein on the coronavirus surface and mediates virus assembly (25):

E protein (envelope protein) is an integral membrane protein and plays a pivotal role in virus envelope formation (27).

Nab represents the neutralizing antibodies, and N/A means not available. 
addition of alum adjuvant exacerbated the immunopathologic reactions $(14,45)$. In alum-adjuvanted SARS-CoV doubleinactivated vaccine (DIV), there was a skew in the $\mathrm{N}$ or $\mathrm{S}$ protein-specific antibodies toward $\mathrm{IgG}_{1}$, when compared with the more balanced antibody production in the nonadjuvanted DIV vaccine (14). These observations raise significant concerns regarding the safety of adjuvanted coronavirus vaccines. On the other hand, it has been shown that alum can reduce immunopathology in SARS-CoV vaccines containing either a double-inactivated virus or S protein (11). Furthermore, in a recent study, a purified inactivated SARS-CoV-2 vaccine (PiCoVacc) adjuvanted with aluminum hydroxide conferred complete protection in non-human primates (rhesus macaques) with potent humoral responses but without lung immunopathology (15). This finding raises the question of the mechanism of eosinophilic immunopathology. While commonly thought of as the product of Th2 responses, recent studies have indicated that tissue eosinophilia can also be controlled by Th17 responses (46). Thus, the proper selection of $\mathrm{CoV}$ antigens and adjuvants that can shift host responses away from a Th17-bias appears to be critical. In addition, other studies have demonstrated that the Th2 immunopathology may be associated with SARS $\mathrm{N}$ or $\mathrm{S}$ protein that results in enhanced eosinophilic immunopathology $(11,37,47)$. However, more studies are required, as the preliminary data is limited. Additionally, the Th-2-biased immune responses may raise the concern on vaccine-enhanced respiratory disease (VAERD) (38, 48), however, there are no evidences that alum-adjuvanted CoV vaccines show the effect.

When alum was used as an adjuvant in $\mathrm{CoV}$ vaccines (Table 1), there was a lack of Th1 $\mathrm{CD}^{+} \mathrm{T}$ cell and cytotoxic $\mathrm{CD}^{+} \mathrm{T}$ cell immune responses, which is typical for alumadjuvanted vaccines (49). However, recent study has demonstrated that the SARS-CoV-2-specific adaptive immune response correlated with milder disease, indicating that coordinated $\mathrm{CD}^{+}$and $\mathrm{CD}^{+} \mathrm{T}$ cell responses play a synergistic effect in the protective immunity of COVID-19 (33). Several other adjuvants, which are capable of inducing more balanced Th1/Th2 or Th1-biased immune responses, have been formulated in $\mathrm{CoV}$ vaccines and will be discussed in the following sections.

\section{EMULSION ADJUVANTS}

The emulsion adjuvants, MF59, and AS03 have already been used in licensed human vaccines to improve the immunogenicity of the antigens $(50,51)$. Compared with alum that lacks the capability to mediate cell-mediated immunity (49), MF59 and AS03 can elicit more balanced immunity, possibly by improving antigen uptake, recruiting immune cells, and promoting the migration of activated antigen-presenting cells (28, 50, 52). Emulsion adjuvants have already been used in preclinical studies of vaccines against coronavirus. MF59 used in inactivated SARS and MERS vaccines, as well as vaccines containing the RBD domain of the MERS-CoV spike (S) protein, has exhibited excellent adjuvanticity, with potent humoral immune responses, i.e., high titers of neutralizing antibodies, and cell-mediated immunity in the coronavirus vaccines (53-55). In addition, depending on the types of antigen, cell-mediated immunity induced by MF59 differs. When formulated with the MERS-CoV S protein, MF59 enhanced both effective $\mathrm{CD}^{+}$and $\mathrm{CD}^{+}$T-cell immune responses. In comparison, when combined with inactivated SARS CoV, MF59 induced significant $\mathrm{CD}^{+} \mathrm{T}$ cell, but not $\mathrm{CD}^{+} \mathrm{T}$ cell responses $(56,57)$. However, in another study by Zhang et al., it was demonstrated that when MERS S protein was adjuvanted with MF59, it induced higher $\operatorname{IgG}_{1}$ and $\operatorname{IgG}_{2 \mathrm{a}}$ antibodies with a slightly Th2-biased response (54). Subsequent studies also showed that ferritin-based MERS-CoV $S$ protein, adjuvanted with MF59, promoted multiple antibody responses, including high levels of IgA antibody titers that resulted in potent mucosal immune responses (58). A study by Tang et al. has indicated that there are no significant differences in the neutralizing activity of the serum derived from mice immunized with MERS S377-588 at 1, 5, and $20 \mu \mathrm{g}$ in the presence of MF59, suggesting the dose-sparing effect of MF59 when it was formulated with MERS S protein (57). However, an immunopathologic lung reaction, as well as an increase in IL-5 and IL-13 cytokines, was seen in animal studies using both MF59adjuvanted and adjuvant-free inactivated MERS-CoV vaccines (53). It has shown that eosinophil infiltrations with higher Th2type cytokine secretion aggravated the hypersensitivity-type pulmonary immunopathology when vaccinated with MF59adjuvanted inactivated virus vaccines as compared with the inactivated virus vaccines alone (53).

Another emulsion adjuvant, AS03, elicits both potent humoral and cellular immune responses to an inactivated whole virion SARS-CoV (WI-SARS) vaccines (59) compared with the virion without adjuvants. Moreover, in the presence of the AS03 adjuvant, an identical trend toward specific $\mathrm{CD}^{+}{ }^{+} \mathrm{T}$ cell responses was observed when immunized with SARS-CoV containing the equivalent of 0.5 or $1.5 \mu \mathrm{g}$ of $\mathrm{S}$ protein (59). Therefore, the addition of AS03 tends to potentiate the immune responses with a lower dosage of antigen. Considering its capability to induce both arms of the immune system, $S$ protein, RBD domain, and $\mathrm{N}$ protein can also be formulated with AS03. Currently, GSK is sharing its AS03 adjuvant with COVID-19 vaccine developers globally (29).

Besides MF59 and AS03, other emulsion-based adjuvants such as Freund's adjuvant and Montanide ISA51 have also been formulated in $\mathrm{CoV}$ vaccines (54). By evaluating the titers of specific serum antibody responses, it has been demonstrated that Freund's adjuvant and ISA51 elicited significant Th1 antibody responses $\left(\operatorname{IgG}_{2 \mathrm{a}}\right)$ with no clear Th2 responses $\left(\operatorname{IgG}_{1}\right)$ $(54,59)$.

\section{TLR AGONISTS AND OTHER ADJUVANTS}

Toll-like receptors (TLRs), a category of pattern-recognition receptors, are critical to pathogen recognition. This allows for 
rapid activation of innate immunity, and subsequently, effective adaptive immunity. TLR agonists have been extensively studied as vaccine adjuvants $(60,61)$. CpG, Poly I:C, glucopyranosyl lipid A (GLA), and resiquimod (R848) are agonists for TLR9, TLR3, TLR4, and TLR7/8, respectively. These adjuvants have been evaluated in candidate vaccines against $\operatorname{SARS} \operatorname{CoV}(62,63)$.

In addition to neutralizing antibodies and $\mathrm{CD} 4^{+} \mathrm{T}$ cells, optimal protection against coronavirus probably involves the synergistic effect of $\mathrm{CD}^{+} \mathrm{T}$ cells (64). Memory $\mathrm{CD} 8^{+} \mathrm{T}$ cells solve the problem of neutralizing antibodies only existing for short periods and providing long-term protective cellular immunity (64). Among the TLR agonists, CpG significantly augments the $\mathrm{CD}^{+} \mathrm{T}$ cell immune response higher than the others (63). Indeed, it has been demonstrated that $\mathrm{CpG}$ can also stimulate enhanced IgG production in animals immunized with an inactivated SARS-CoV vaccine (62). In addition to IgG, IgA production was also enhanced, only when CpG was administered via intranasal (i.n.) administration (62), indicating immune activation in the mucosal compartment. Although CpG is capable of inducing both cellular and humoral immune responses, it preferentially induces responses that are Th1-biased. Moreover, CpG can divert pre-existing Th2 responses to a Th1 phenotype, which has laid a foundation for the combination of CpG with other adjuvants, most commonly alum (65). In SARS-CoV or MERS-CoV subunit vaccines, studies have found that the combination of alum and CpG elicited higher neutralization antibody titers and a more robust cellular immune response compared with alum alone or alum with other TLR agonists $(18,19)$. In addition to alum, $\mathrm{CpG}$ is combined with Montanide ISA-51, a type of water-in-oil emulsion adjuvant. When the combined adjuvants were formulated with SARS S or N protein, they were capable of promoting robust neutralizing antibody production (66). However, vaccinated with only SARS N protein, animals showed immune responses biased dramatically toward Th1 (67). In addition, it is reported that R848 could enhance antigenspecific CTL response and induce a fast, robust and durable IFN- $\alpha$ production in vivo among humanized mice, which is distinct from the experimental findings based on common mouse models (68). However, further studies on R848 adjuvanticity should stress more on vaccine formulation. A recent study by Gadd et al. indicated that only when R848 was conjugated with DOPE (1,2-di-(9Z -octadecenoyl)-sn-glycero-3-phosphoethanolamine):DDA (dimethyldioctadecylammonium bromide salt) multilamella liposomes rather than linear mixed, a high potency of immunostimulatory activity was observed (69). Moreover, an R848-encapsulating PLGA nanoparticle can bring down the excessive level of inflammatory cytokines induced by free R848, which could be benefit to provide long-term safety and appropriate immune response (70).

Although CpG had been shown to exhibit considerable potential as a coronavirus-specific adjuvant, studies have found that it might be a poor inducer of long-term immune memory (46). A recent study indicated that single-stranded RNAs (ssRNAs) derived from the Cricket paralysis virus (CrPV) intergenic region (IGR) internal ribosome entry sites (IRES) could function as vaccine adjuvants endowing long-lasting immunity. This adjuvant significantly activates innate immune response through activating TLR7 and enhancing the chemotaxis of professional antigen-presenting cells (APC) (71). Moreover, some novel adjuvants such as STING agonist, Advax, and $\mathrm{ASO1}_{\mathrm{B}}$, which is an adjuvant formulated in recombinant zoster vaccine Shingrix, exhibit advantages for long-lasting immune responses $(46,59,72)$. Advax, a delta inulin microparticle adjuvant, augmented the induction of neutralizing antibodies along with the existence of memory B cells and a robust, long-lasting T-cell IFN- $\gamma$ response when it was formulated in recombinant or inactivated SARS-CoV vaccines (46). Moreover, Matrix M1, a saponin-based adjuvant, has been demonstrated to be more effective than alum adjuvant in inducing neutralizing antibodies to SARS S protein or MERS S protein (17). This might address the concern that $S$ protein may lead to antibody-dependent enhancement (ADE), which is more likely to be triggered by mild antibody production (36).

The SARS-CoV-2 infections occur at the mucosal surface of the upper respiratory tract (73). Thus, the elicitation of protective immune responses at the mucosa is critical. TLR agonists, such as flagellin (74) and CpG ODN (62), have been used as mucosal adjuvants. As discussed above, the $\mathrm{CpG}$ ODN can elicit neutralizing antibodies in mucosal compartments (62) when formulated with inactivated SARS-CoV. Additionally, the STING agonist, bis- $\left(3^{\prime}, 5^{\prime}\right)$-cyclic dimeric guanosine monophosphate (c-di-GMP or cdGMP), has been reported as a potent mucosal vaccine adjuvant that induces Th1 and Th17 cytokines in a plant-derived $\mathrm{H} 5$ influenza vaccine after intranasal vaccination (75). In a very recent study, it was demonstrated that pulmonary surfactant-biomimetic liposomes encapsulating STING agonists could be used as mucosal adjuvants for universal influenza vaccines that trigger rapid humoral and cellular immune responses and exhibit sustained crossprotection against influenza (76). Though cdGMP in polymeric nanoparticle formulations has been used as adjuvants with MERS-CoV S-RBD protein, its ability to induce mucosal immunity was not specifically examined (72). Thus, further studies are warranted to examine both the efficacy and safety of mucosal adjuvants in coronavirus vaccines.

\section{CONCLUSION AND PERSPECTIVES}

In this article, we provided an overview of previously studied adjuvants in candidate inactivated and subunit coronavirus vaccines with a focus on the types of adjuvants in the vaccine formulations and the nature of immune responses to the formulated vaccines. These previous studies provided a convenient basis for the screening of adjuvants required to develop coronavirus vaccines. In-depth reviews of the various adjuvants, a comprehensive understanding of their impacts on the extent and types of immune responses, and an exploration of their combinations with various antigen types and vaccine platforms will facilitate the selection of adjuvants that provide the required immunological protection of coronavirus vaccines.

In the absence of a cure for COVD-19, effective and safe vaccines are urgently required. Adjuvants such as aluminumbased salts, TLR agonists, emulsions, and other novel adjuvants 
TABLE 2 | Emulsion adjuvants used in the coronavirus vaccine formulations under exploratory and pre-clinical investigations.

\begin{tabular}{|c|c|c|c|c|c|c|c|c|c|c|c|c|c|c|c|c|c|}
\hline \multirow{2}{*}{$\begin{array}{l}\text { Adjuvant } \\
\text { Type }\end{array}$} & \multirow[t]{2}{*}{ Platform } & \multirow[t]{2}{*}{ Adjuvant } & \multirow[t]{2}{*}{ Antigen } & \multirow[t]{2}{*}{ Antigen Dose } & \multicolumn{8}{|c|}{ Immunological response } & \multirow{2}{*}{ Route } & \multirow{2}{*}{$\begin{array}{l}\text { Immunization } \\
\text { Schedule }\end{array}$} & \multirow[t]{2}{*}{ Safety } & \multirow[t]{2}{*}{ Animal model } & \multirow[t]{2}{*}{ Ref. } \\
\hline & & & & & Nab & $\operatorname{lgG}_{1}$ & $\lg _{2 a}$ & $\lg A$ & $\begin{array}{c}\text { Th1 } \\
\text { cytokines }\end{array}$ & $\begin{array}{c}\text { Th2 } \\
\text { cytokines }\end{array}$ & $\begin{array}{c}\text { Th17 } \\
\text { Cytokines }\end{array}$ & $\begin{array}{c}\mathrm{CD}^{+} \\
\mathrm{T} \text { cell } \\
\text { response }\end{array}$ & & & & & \\
\hline \multirow[t]{16}{*}{$\begin{array}{l}\text { Emulsion } \\
\text { adjuvants }\end{array}$} & $\begin{array}{l}\text { Inactivated } \\
\text { vaccines }\end{array}$ & MF59-like & $\begin{array}{l}\text { Inactivated MERS } \\
\text { virus }\end{array}$ & $100 \mu \mathrm{l}\left(1 \times 10^{7} \mathrm{TCID}_{50} / \mathrm{ml}\right)$ & $\checkmark$ & N/A & N/A & N/A & $\checkmark$ & $\checkmark$ & N/A & N/A & i.m. & 2 & $\begin{array}{l}\text { Lung } \\
\text { immunopathology }\end{array}$ & $\begin{array}{l}\text { hCD26/DPP4 Tg } \\
\text { mice }\end{array}$ & (53) \\
\hline & $\begin{array}{l}\text { Inactivated } \\
\text { vaccines }\end{array}$ & MF59 & $\begin{array}{l}\text { Inactivated SARS } \\
\text { virus }\end{array}$ & $5 \mu \mathrm{g}$ & $\sqrt{ }$ & N/A & N/A & N/A & $\checkmark$ & N/A & N/A & $x$ & i.m. & 2 & $N / A$ & BALB/c mice & (56) \\
\hline & $\begin{array}{l}\text { Inactivated } \\
\text { vaccines }\end{array}$ & ASO3 & $\begin{array}{l}\text { Inactivated SARS } \\
\text { virus }\end{array}$ & $\begin{array}{l}100 \mu \mathrm{L} \text { of WI-SARS } \\
\text { containing the equivalent } \\
\text { of } 0.5 / 1.0 / 1.5 \mu \mathrm{g} \text { of } \mathrm{S} \\
\text { protein }\end{array}$ & $\sqrt{ }$ & N/A & N/A & N/A & $\checkmark$ & N/A & N/A & $x$ & i.m. & 2 & N/A & BALB/c mice & (59) \\
\hline & $\begin{array}{l}\text { Subunit } \\
\text { vaccines }\end{array}$ & MF59 & $\begin{array}{l}\text { MERS-CoV S- } \\
\text { RBD-Fc protein }\end{array}$ & $10 \mu \mathrm{g}$ & $\sqrt{ }$ & $\checkmark$ & $\checkmark$ & $\mathrm{N} / \mathrm{A}$ & $x$ & N/A & N/A & $x$ & s.c. & 3 & N/A & $\begin{array}{l}\text { BALB/c mice; Ad5- } \\
\text { hDPP4 mice }\end{array}$ & (54) \\
\hline & $\begin{array}{l}\text { Subunit } \\
\text { vaccines }\end{array}$ & MF59 & $\begin{array}{l}\text { MERS-CoV S- } \\
\text { RBD-Fc protein }\end{array}$ & 1/5/20 $\mu \mathrm{g}$ (optimal: $1 \mu \mathrm{g}$ ) & $\sqrt{ }$ & $\sqrt{ }$ & $\sqrt{ }$ & N/A & $\checkmark$ & N/A & N/A & $\checkmark$ & s.c. & 3 & N/A & BALB/c mice & (57) \\
\hline & $\begin{array}{l}\text { Subunit } \\
\text { vaccines }\end{array}$ & MF59-like & $\begin{array}{l}\text { MERS-CoV S- } \\
\text { RBD-Fc protein }\end{array}$ & $10 \mu \mathrm{g}$ & $\sqrt{ }$ & $\mathrm{N} / \mathrm{A}$ & N/A & $\mathrm{N} / \mathrm{A}$ & N/A & N/A & $\mathrm{N} / \mathrm{A}$ & N/A & i.m. & 2 & $\begin{array}{l}\text { Weight loss and } \\
\text { death of mice }\end{array}$ & $\begin{array}{l}\text { hCD26/DPP4 Tg } \\
\text { mice }\end{array}$ & (78) \\
\hline & $\begin{array}{l}\text { Subunit } \\
\text { vaccines }\end{array}$ & MF59 & $\begin{array}{l}\text { MERS-CoV S- } \\
\text { RBD-Fc protein }\end{array}$ & $10 \mu \mathrm{g}$ & v & $\checkmark$ & $\checkmark$ & $\mathrm{N} / \mathrm{A}$ & N/A & N/A & N/A & N/A & s.c. & 2 & N/A & $\begin{array}{l}\text { BALB/c mice; } \\
\text { hDPP4-Tg mice }\end{array}$ & (79) \\
\hline & $\begin{array}{l}\text { Subunit } \\
\text { vaccines }\end{array}$ & MF59-like & $\begin{array}{l}\text { MERS-CoV S- } \\
\text { RBD-Fc protein }\end{array}$ & $10 \mu \mathrm{g}$ & $\checkmark$ & N/A & N/A & N/A & $\checkmark$ & N/A & N/A & N/A & i.m. & 2 & N/A & $\begin{array}{l}\mathrm{CD} 26 / \mathrm{hDPP} 4 \mathrm{Tg} \\
\text { mice }\end{array}$ & (55) \\
\hline & $\begin{array}{l}\text { Subunit } \\
\text { vaccines }\end{array}$ & MF59 & $\begin{array}{l}\text { MERS-CoV S- } \\
\text { RBD-Fd protein }\end{array}$ & $10 \mu \mathrm{g}$ & v & $\sqrt{ }$ & 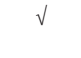 & N/A & N/A & N/A & $\mathrm{N} / \mathrm{A}$ & N/A & s.c. & 4 & $\mathrm{~N} / \mathrm{A}$ & $\begin{array}{l}\text { BALB/c mice; } \\
\text { hDPP4-Tg mice }\end{array}$ & (80) \\
\hline & $\begin{array}{l}\text { Subunit } \\
\text { vaccines }\end{array}$ & MF59-like & $\begin{array}{l}\text { MERS-CoV S- } \\
\text { RBD protein NPS }\end{array}$ & $20 \mu \mathrm{g}$ & N/A & $\sqrt{ }$ & $\checkmark$ & $\checkmark$ & $\checkmark$ & N/A & N/A & N/A & i.m. & 3 & N/A & BALB/c mice & (58) \\
\hline & $\begin{array}{l}\text { Subunit } \\
\text { vaccines }\end{array}$ & MF59-like & $\begin{array}{l}\text { MERS-CoV S- } \\
\text { RBD protein }\end{array}$ & $10 \mu \mathrm{g}$ & N/A & $\checkmark$ & $\checkmark$ & N/A & $x$ & N/A & N/A & $x$ & s.c. & 2 & N/A & C57BL/6 mice & (72) \\
\hline & $\begin{array}{l}\text { Subunit } \\
\text { vaccines }\end{array}$ & MF59-like & $\begin{array}{l}\text { MERS-CoV/ } \\
\text { SARS-CoV/ } \\
\text { SARS-CoV-2 } \\
\text { RBD-sc-dimer }\end{array}$ & $10 \mu \mathrm{g}$ & $\sqrt{ }$ & N/A & N/A & N/A & $\times$ & $\times$ & N/A & $x$ & i.m. & 3 & $\mathrm{~N} / \mathrm{A}$ & BALB/c mice & (23) \\
\hline & $\begin{array}{l}\text { Subunit } \\
\text { vaccines }\end{array}$ & $\begin{array}{l}\text { Montanide } \\
\text { ISA51 }\end{array}$ & $\begin{array}{l}\text { MERS-CoV S- } \\
\text { RBD-Fc protein }\end{array}$ & $10 \mu \mathrm{g}$ & v & $x$ & $\checkmark$ & N/A & $x$ & N/A & N/A & $x$ & s.c. & 3 & N/A & $\begin{array}{l}\text { BALB/c mice; Ad5- } \\
\text { hDPP4 mice }\end{array}$ & (54) \\
\hline & $\begin{array}{l}\text { Subunit } \\
\text { vaccines }\end{array}$ & $\begin{array}{l}\text { Freund's } \\
\text { adjuvant }\end{array}$ & $\begin{array}{l}\text { MERS-CoV } \\
\text { S-RBD-Fc protein }\end{array}$ & $10 \mu \mathrm{g}$ & $x$ & $x$ & $\checkmark$ & N/A & $x$ & N/A & N/A & $x$ & s.c. & 3 & N/A & $\begin{array}{l}\text { BALB/c mice; Ad5- } \\
\text { hDPP4 mice }\end{array}$ & (54) \\
\hline & $\begin{array}{l}\text { Subunit } \\
\text { vaccines }\end{array}$ & $\begin{array}{l}\text { Ribi } \\
\text { adjuvants }\end{array}$ & $\begin{array}{l}\text { MERS-CoV S1 } \\
\text { protein }\end{array}$ & $10 \mu \mathrm{g}$ & $\sqrt{ }$ & $\sqrt{ }$ & $\sqrt{ }$ & $\mathrm{N} / \mathrm{A}$ & N/A & N/A & N/A & $\mathrm{N} / \mathrm{A}$ & i.m. & 2 & N/A & BALB/c mice & (22) \\
\hline & $\begin{array}{l}\text { Subunit } \\
\text { vaccines }\end{array}$ & $\begin{array}{l}\text { Alum- } \\
\text { stabilized } \\
\text { Pickering } \\
\text { emulsion } \\
\text { (PAPE) }\end{array}$ & $\begin{array}{l}\text { Recombinant } \\
\text { RBD of } \\
\text { SARS-CoV-2 }\end{array}$ & $5 \mu \mathrm{g}$ & $\mathrm{N} / \mathrm{A}$ & $\sqrt{ }$ & $\sqrt{ }$ & N/A & $\checkmark$ & $\checkmark$ & N/A & N/A & i.m. & 2 & $\begin{array}{l}\text { Acceptable } \\
\text { biosafety }\end{array}$ & BALB/c mice & (81) \\
\hline
\end{tabular}

Annotation:

MF59 adjuvant an emulsion adjuvant composed of an oil phase (squalene:4.3\%): and an aqueous phase (polysorbate 80:0.5\%, sorbitan trioleate:0.5\%);

MF59-like (AddaVax): a squalene-based oil-in-water nano-emulsion based on the formulation of MF59 (squalene:5\%, polysorbate 80:0.5\%, and sorbitan trioleate:0.5\%);

ASO3 adjuvant: an emulsion adjuvant composed of an oil phase (10.69 $\mathrm{mg}$ squalene, $11.86 \mathrm{mg} \mathrm{DL}$ - $\alpha$-tocopherol) and an aqueous phase (4.86 mg polysorbate 80) each 0.5-mL adult dose;

Ribi adjuvant: an oil-in-water emulsion containing $2 \%$ squalene-Tween 80 -water, $0.5 \mathrm{mg}$ monophosphoryl lipid A, and $0.5 \mathrm{mg}$ synthetic trehalose dicorynomycolate;

Montanide ISA-51: a water-in-oil (W/O) emulsion adjuvant composed of a mineral oil and a surfactant from the mannide monooleate family;

Freund's adjuvant: heat-killed mycobacterium tuberculosis in non-metabolizable olls (paraffin oil and mannide monooleate);

Nab represents the neutralizing antibodies, and N/A means not available. 
TABLE 3 | TLR agonists and other adjuvants used in the coronavirus vaccine formulations under exploratory and pre-clinical investigations.

\begin{tabular}{|c|c|c|c|c|c|c|c|c|c|c|c|c|c|c|c|c|c|}
\hline \multirow{2}{*}{$\begin{array}{l}\text { Adjuvant } \\
\text { Type }\end{array}$} & \multirow[t]{2}{*}{ Platform } & \multirow[t]{2}{*}{ Adjuvant } & \multirow[t]{2}{*}{ Antigen } & \multirow{2}{*}{$\begin{array}{l}\text { Antigen } \\
\text { Dose }\end{array}$} & \multicolumn{8}{|c|}{ Immunological response } & \multirow[t]{2}{*}{ Route } & \multirow{2}{*}{$\begin{array}{l}\text { Immunization } \\
\text { Schedule }\end{array}$} & \multirow[t]{2}{*}{ Safety } & \multirow[t]{2}{*}{ Animal model } & \multirow[t]{2}{*}{ Ref. } \\
\hline & & & & & $\mathrm{Nab}$ & $\lg G_{1}$ & $\lg _{2 a}$ & $\lg A$ & $\begin{array}{c}\text { Th1 } \\
\text { cytokines }\end{array}$ & $\begin{array}{c}\text { Th2 } \\
\text { cytokines }\end{array}$ & $\begin{array}{l}\text { Th17 } \\
\text { Cytokines }\end{array}$ & $\begin{array}{l}\mathrm{CD8}^{+} \mathrm{T} \text { cell } \\
\text { response }\end{array}$ & & & & & \\
\hline \multirow[t]{11}{*}{$\begin{array}{l}\text { TLR } \\
\text { agonists }\end{array}$} & Inactivated vaccines & CpG ODN 2006 & $\begin{array}{l}\text { inactivated SARS-CoV } \\
\text { (SARS-CoV Z-1 strain virus) }\end{array}$ & $10 \mu \mathrm{g}$ & $\checkmark$ & N/A & N/A & N/A & N/A & $\mathrm{N} / \mathrm{A}$ & N/A & $\sqrt{ }$ & i.n./i.p. & 3 & N/A & BALB/c mice & (62) \\
\hline & Subunit vaccines & Monophosphoryl lipid A & $\begin{array}{l}\text { MERS-CoV S-RBD-FC } \\
\text { protein }\end{array}$ & $10 \mu \mathrm{g}$ & $\sqrt{ }$ & $\sqrt{ }$ & $x$ & $\mathrm{~N} / \mathrm{A}$ & $x$ & N/A & N/A & $x$ & s.c. & 3 & N/A & $\begin{array}{c}\text { BALB/c mice; } \\
\text { Ad5-hDPP4 mice }\end{array}$ & (54) \\
\hline & Subunit vaccines & CpG ODN 1826 & 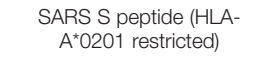 & $20 \mu \mathrm{g}$ & N/A & $\mathrm{N} / \mathrm{A}$ & N/A & $x$ & $x$ & N/A & v & N/A & s.c. & 2 & N/A & $\begin{array}{l}\text { HLA-A }{ }^{*} 0201 \mathrm{Tg} \\
\text { mice }\end{array}$ & (63) \\
\hline & Subunit vaccines & Poly(l:C) & 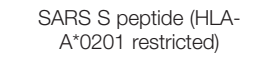 & $20 \mu g$ & $\mathrm{~N} / \mathrm{A}$ & $\mathrm{N} / \mathrm{A}$ & $\mathrm{N} / \mathrm{A}$ & $x$ & $\times$ & N/A & $\sqrt{ }$ & N/A & s.c. & 2 & N/A & & (63) \\
\hline & Subunit vaccines & R848 & $\begin{array}{l}\text { SARS S peptide (HLA- } \\
\text { A*0201 restricted) }\end{array}$ & $20 \mu \mathrm{g}$ & $\mathrm{N} / \mathrm{A}$ & $\mathrm{N} / \mathrm{A}$ & N/A & $x$ & $x$ & N/A & $\checkmark$ & N/A & s.c. & 2 & N/A & & (63) \\
\hline & Subunit vaccines & $\begin{array}{l}\text { CpG ODN } 1826+ \\
\text { Alhydrogel }\end{array}$ & SARS S protein & $8 \mu \mathrm{g}$ & $\checkmark$ & $\checkmark$ & $\checkmark$ & $\checkmark$ & $\checkmark$ & N/A & N/A & $\checkmark$ & s.c. & 2 & N/A & 129S6/SvEv mice & (19) \\
\hline & Subunit vaccines & $\begin{array}{l}\text { CpG+aluminum } \\
\text { oxyhydroxide }\end{array}$ & MERS S protein & $10 \mu \mathrm{g}$ & $\checkmark$ & $\checkmark$ & $\checkmark$ & $\checkmark$ & $\checkmark$ & N/A & N/A & $\checkmark$ & i.m. & 3 & $\mathrm{~N} / \mathrm{A}$ & BALB/c mice & (18) \\
\hline & Subunit vaccines & CpG+ Montanide ISA-51 & SARS S protein & $30 \mu \mathrm{g}$ & N/A & N/A & N/A & N/A & N/A & N/A & $N / A$ & N/A & s.c. & 3 & N/A & BALB/c mice & (66) \\
\hline & Subunit vaccines & CpG+ Montanide ISA-51 & SARS $N$ protein & $50 \mu \mathrm{g}$ & N/A & $\sqrt{ }$ & $\checkmark$ & $\sqrt{ }$ & $\mathrm{N} / \mathrm{A}$ & N/A & $\checkmark$ & N/A & s.c. & 3 & N/A & $\begin{array}{c}\text { BALB/c } \\
\text { mice; Macaques }\end{array}$ & (67) \\
\hline & Subunit vaccines & $\begin{array}{l}\text { GLA+ Alhydrogel or } \\
\text { aluminum phosphate }\end{array}$ & $\begin{array}{l}\text { RBD (S318-510) of the } \\
\text { SARS-CoV S protein }\end{array}$ & N/A & v & $\checkmark$ & $\checkmark$ & N/A & N/A & N/A & N/A & $\checkmark$ & i.m. & 2 & N/A & $\begin{array}{l}\text { BALB/c } \\
\text { mice }\end{array}$ & (82) \\
\hline & Subunit vaccines & $\begin{array}{l}\text { SsRNA+ } \\
\text { aluminum hydroxide }\end{array}$ & MERS-CoV S protein & $1 \mu \mathrm{g}$ & v & $\checkmark$ & N/A & $\checkmark$ & N/A & N/A & $\checkmark$ & $\checkmark$ & i.m. & 2 & N/A & hDPP4 Tg mice & (71) \\
\hline \multirow[t]{4}{*}{ Others } & Inactivated vaccines & $\mathrm{ASO1}_{\mathrm{B}}$ & SARS inactivated whole virus & $0.5 / 1 \mu \mathrm{g}$ & $\checkmark$ & N/A & N/A & N/A & N/A & N/A & $x$ & $\checkmark$ & i.m. & 2 & N/A & $\begin{array}{c}\text { BALB/c } \\
\text { mice; Hamsters }\end{array}$ & (59) \\
\hline & $\begin{array}{l}\text { Inactivated vaccines } \\
\text { /Subunit vaccines }\end{array}$ & Advax & $\begin{array}{c}\text { SARS S protein/inactivated } \\
\text { whole virus }\end{array}$ & $1 \mu \mathrm{g}$ & $\sqrt{ }$ & $\checkmark$ & $\checkmark$ & $\checkmark$ & $\sqrt{ }$ & $\sqrt{ }$ & $\checkmark$ & $\checkmark$ & i.m. & 2 & N/A & $\begin{array}{l}\text { BALB/c } \\
\text { mice }\end{array}$ & (46) \\
\hline & Subunit vaccines & Matrix M1 & $\begin{array}{c}\text { SARS S protein/MERS S } \\
\text { protein }\end{array}$ & $\begin{array}{c}1 / 3 / 10 \\
\mu \mathrm{g}\end{array}$ & $\sqrt{ }$ & $\mathrm{N} / \mathrm{A}$ & N/A & N/A & N/A & N/A & $\mathrm{N} / \mathrm{A}$ & $\checkmark$ & i.m. & 2 & N/A & $\begin{array}{l}\text { BALB/c } \\
\text { mice }\end{array}$ & (17) \\
\hline & Subunit vaccines & NP-cdGMP & MERS-CoV S-RBD protein & $10 \mu g$ & N/A & $\sqrt{ }$ & v & $\mathrm{N} / \mathrm{A}$ & v & $\sqrt{ }$ & $\sqrt{ }$ & $\sqrt{ }$ & s.c. & 2 & N/A & C57BL/6 mice & (72) \\
\hline
\end{tabular}

Annotation:

MPLA (monophosphoryl lipid A): a low-toxicity derivative of lipopolysaccharide (LPS), that retains the immunologically active lipid A portion of the parent molecule;

CpG ODN: synthetic oligodeoxynucleotides containing unmethylated CpG motifs;

Polyl:C (Polyinosinic-polycytidylic acid): a synthetic analog of double-stranded RNA (dsRNA), a molecular pattern associated with viral infection;

R848 (resiquimod): a small molecular weight imidazoquinoline compound, an immune response modifier with potent antiviral and antitumor activities;

GLA: glucopyranosyl lipid A, a synthetic Toll-like receptor 4 (TLR4) agonist;

Advax: a novel microcrystalline polysaccharide particle engineered from delta inulin;

AS01 : a liposome-based emulsion adjuvant system containing two immunostimulants, 3-O-desacyl-4'-monophosporyl lipid A (MPL) and the saponin QS-21:

Matrix M1: consists of two individually formed 40-nm-sized particles, each with a different and well-characterized saponin fraction (Fraction-A and Fraction-C);

NP-cdGMP: cyclic diguanylate monophosphate (cdGMP), a canonical STING (stimulator of interferon genes) agonist, encapsulated into PLGA-based hollow nanoparticles.

Nab represents the neutralizing antibodies, and N/A means not available. 
have distinctive physicochemical properties, which can be significant in regulating the strength, duration, and types of immune responses $(19,63,77)$. Studies have suggested that neutralizing antibodies are critical for immune protection (34, 42).While mechanistic studies are still being conducted, emerging evidence has suggested that SRAS-CoV-2-specific $\mathrm{CD}^{+}$and $\mathrm{CD}^{+} \mathrm{T}$ cells in coordination with neutralizing antibodies are required for generating protective immunity against SARS-CoV-2 (33). Thus, the appropriate adjuvants should be selected to formulate specific antigens that will achieve optimal immunogenicity profiles. Current available studies have demonstrated the feasibility of formulating $S$ protein, RBD domain, $\mathrm{M}$ protein and $\mathrm{N}$ protein with specific adjuvants.

It should be noted that the development of a COVID-19 vaccine has been on a fast track. Thus far, four non-replicating viral vector vaccines, three inactivated vaccines and two mRNA vaccines being under clinical phase III stage, with more are on the way (32). Though different types of adjuvants have been used in exploratory and pre-clinical studies (Tables 1-3), considering the need for rapid deployment of COVID-19 vaccines for the pandemic, alum, which had been formulated in many other licensed vaccines, have been prioritized $(15,16)$. In addition to the adjuvants described above, engineered nanomaterials also shed light adjuvant development. It has been shown that physicochemical characteristics of aluminum oxyhydroxide could affect the optimal immunogenicity profiles of vaccine formulations $(41,83,84)$. Moreover, a recent study has shown that an alum-stabilized Pickering emulsion (PAPE) showed robust $\mathrm{RBD}$-specific $\operatorname{IgG}_{1}$ and $\mathrm{IgG}_{2 \mathrm{a}}$ titers and a high level of inducing IFN- $\gamma$-secreting $\mathrm{T}$ cells in a COVID-19 vaccine. Additionally, it has been shown that a natural and potent STING agonist encapsulated by pulmonary biomimetic liposomes triggered rapid humoral and cellular immune responses and exhibited a sustained cross-protection against influenza (76). However, more comprehensive mechanistic studies, including the nature of protective immune responses and screening of the various combinations of antigens and adjuvants, are needed for the successful development of a safe and effective COVID-19 vaccine.

\section{AUTHOR CONTRIBUTIONS}

ZLiang, HZhu, XW, BJ, and XX wrote the manuscript. BS, LS and HZeng conceived and revised the manuscript. HS, YY, and WZ provided critical suggestions. All authors contributed to the article and approved the submitted version.

\section{FUNDING}

This work was supported by the National Natural Science Foundation of China (31870919), Natural Science Foundation of Liaoning Province (No. 20180550597), LiaoNing Revitalization Talents Program (XLYC1807113), Dalian Science and Technology Innovation Fund (No. 2020JJ25CY015), and Fundamental Research Funds for the Central Universities (DUT19TD12).

\section{REFERENCES}

1. Fehr AR, Perlman S. Coronaviruses: an overview of their replication and pathogenesis. Methods Mol Biol (2015) 1282:1-23. doi: 10.1007/978-1-49392438-7_1

2. Lu S. Timely development of vaccines against SARS-CoV-2. Emerg Microbes Infect (2020) 9:542-4. doi: 10.1080/22221751.2020.1737580

3. Lau EHY, Hsiung CA, Cowling BJ, Chen CH, Ho LM, Tsang T, et al. A comparative epidemiologic analysis of SARS in Hong Kong, Beijing and Taiwan. BMC Infect Dis (2010) 10:50. doi: 10.1186/1471-2334-10-50

4. World Health Organization. Middle East respiratory syndrome coronavirus (MERS-CoV) (2020). Available at: http://www.who.int/emergencies/merscov/en/ (Accessed October 1, 2020).

5. World Health Organization. WHO COVID-19 dashboard (2020). Available at: https://www.who.int/emergencies/diseases/novel-coronavirus-2019 (Accessed October 1, 2020).

6. Liu C, Zhou Q, Li Y, Garner LV, Watkins SP, Carter LJ, et al. Research and Development on Therapeutic Agents and Vaccines for COVID-19 and Related Human Coronavirus Diseases. ACS Cent Sci (2020) 6:315-31. doi: 10.1021/acscentsci.0c00272

7. Van Doremalen N, Lambe T, Spencer A, Belij-Rammerstorfer S, Purushotham JN, Port JR, et al. ChAdOx1 nCoV-19 vaccination prevents SARS-CoV-2 pneumonia in rhesus macaques. BioRxiv (2020) 586:578-82. doi: $10.1101 / 2020.05 .13 .093195$

8. Lasaro MO, Ertl HC. New insights on adenovirus as vaccine vectors. Mol Ther (2009) 17:1333-9. doi: 10.1038/mt.2009.130

9. Koirala A, Joo YJ, Khatami A, Chiu C, Britton PN. Vaccines for COVID-19: The current state of play. Paediatr Respir Rev (2020) 35:43-9. doi: 10.1016/ j.prrv.2020.06.010

10. Okba NM, Raj VS, Haagmans BL. Middle East respiratory syndrome coronavirus vaccines: current status and novel approaches. Curr Opin Virol (2017) 23:49-58. doi: 10.1016/j.coviro.2017.03.007

11. Tseng CT, Sbrana E, Iwata-Yoshikawa N, Newman PC, Garron T, Atmar RL, et al. Immunization with SARS coronavirus vaccines leads to pulmonary immunopathology on challenge with the SARS virus. PLoS One (2012) 7: e35421. doi: 10.1371/journal.pone.0035421

12. Takasuka N, Fujii H, Takahashi Y, Kasai M, Morikawa S, Itamura S, et al. A subcutaneously injected UV-inactivated SARS coronavirus vaccine elicits systemic humoral immunity in mice. Int Immunol (2004) 16:1423-30. doi: 10.1093/intimm/dxh143

13. Spruth M, Kistner O, Savidis-Dacho H, Hitter E, Crowe B, Gerencer M, et al. A double-inactivated whole virus candidate SARS coronavirus vaccine stimulates neutralising and protective antibody responses. Vaccine (2006) 24:652-61. doi: 10.1016/j.vaccine.2005.08.055

14. Bolles M, Deming D, Long K, Agnihothram S, Whitmore A, Ferris M, et al. A double-inactivated severe acute respiratory syndrome coronavirus vaccine provides incomplete protection in mice and induces increased eosinophilic proinflammatory pulmonary response upon challenge. J Virol (2011) 85:12201-15. doi: 10.1128/JVI.06048-11

15. Gao Q, Bao L, Mao H, Wang L, Xu K, Yang M, et al. Rapid development of an inactivated vaccine for SARS-CoV-2. Science (2020) 369:77-81. doi: 10.1101/ 2020.04.17.046375

16. Wang H, Zhang Y, Huang B, Deng W, Quan Y, Wang W, et al. Development of an Inactivated Vaccine Candidate, BBIBP-CorV, with Potent Protection against SARS-CoV-2. Cell (2020) 182:713-21.e9. doi: 10.1016/ j.cell.2020.06.008

17. Coleman CM, Liu YV, Mu H, Taylor JK, Massare M, Flyer DC, et al. Purified coronavirus spike protein nanoparticles induce coronavirus neutralizing 
antibodies in mice. Vaccine (2014) 32:3169-74 doi: 10.1016/ j.vaccine.2014.04.016

18. Lan J, Deng Y, Chen H, Lu G, Wang W, Guo X, et al. Tailoring subunit vaccine immunity with adjuvant combinations and delivery routes using the Middle East respiratory coronavirus (MERS-CoV) receptor-binding domain as an antigen. PLoS One (2014) 9:e112602. doi: 10.1371/journal.pone.0112602

19. Zakhartchouk AN, Sharon C, Satkunarajah M, Auperin T, Viswanathan S, Mutwiri G, et al. Immunogenicity of a receptor-binding domain of SARS coronavirus spike protein in mice: implications for a subunit vaccine. Vaccine (2007) 25:136-43. doi: 10.1016/j.vaccine.2006.06.084

20. Zhou Z, Post P, Chubet R, Holtz K, McPherson C, Petric M, et al. A recombinant baculovirus-expressed $\mathrm{S}$ glycoprotein vaccine elicits high titers of SARS-associated coronavirus (SARS-CoV) neutralizing antibodies in mice. Vaccine (2006) 24:3624-31. doi: 10.1016/j.vaccine.2006.01.059

21. Lan J, Yao Y, Deng Y, Chen H, Lu G, Wang W, et al. Recombinant Receptor Binding Domain Protein Induces Partial Protective Immunity in Rhesus Macaques Against Middle East Respiratory Syndrome Coronavirus Challenge. Ebiomedicine (2015) 2:1438-46. doi: 10.1016/j.ebiom.2015.08.031

22. Wang L, Shi W, Joyce MG, Modjarrad K, Zhang Y, Leung K, et al. Evaluation of candidate vaccine approaches for MERS-CoV. Nat Commun (2015) 6:7712. doi: $10.1038 /$ ncomms 8712

23. Dai L, Zheng T, Xu K, Han Y, Xu L, Huang E, et al. A Universal Design of Betacoronavirus Vaccines against COVID-19, MERS, and SARS. Cell (2020) 182:722-33. doi: 10.1016/j.cell.2020.06.035

24. Yang J, Wang W, Chen Z, Lu S, Yang F, Bi Z, et al. A vaccine targeting the $\mathrm{RBD}$ of the $\mathrm{S}$ protein of SARS-CoV-2 induces protective immunity. Nature (2020) 586:572-7. doi: 10.1038/s41586-020-2599-8

25. Du L, He Y, Zhou Y, Liu S, Zheng BJ, Jiang S. The spike protein of SARS$\mathrm{CoV}$-a target for vaccine and therapeutic development. Nat Rev Microbiol (2009) 7:226-36. doi: 10.1038/nrmicro2090

26. Kang $\mathrm{S}$, Yang $M$, Hong Z, Zhang L, Huang Z, Chen X, et al. Crystal structure of SARS-CoV-2 nucleocapsid protein RNA binding domain reveals potential unique drug targeting sites. Acta Pharm Sin B (2020) 10:1228-38. doi: 10.1016/j.apsb.2020.04.009

27. Maeda J, Repass JF, Maeda A, Makino S. Membrane topology of coronavirus E protein. Virology (2001) 281:163-9. doi: 10.1006/viro.2001.0818

28. Shi S, Zhu H, Xia X, Liang Z, Ma X, Sun B. Vaccine adjuvants: Understanding the structure and mechanism of adjuvanticity. Vaccine (2019) 37:3167-78. doi: 10.1016/j.vaccine.2019.04.055

29. Thanh Le T, Andreadakis Z, Kumar A, Gomez Roman R, Tollefsen S, Saville $\mathrm{M}$, et al. The COVID-19 vaccine development landscape. Nat Rev Drug Discov (2020) 19:305-6. doi: 10.1038/d41573-020-00073-5

30. McPherson C, Chubet R, Holtz K, Honda-Okubo Y, Barnard D, Cox M, et al. Development of a SARS Coronavirus Vaccine from Recombinant Spike Protein Plus Delta Inulin Adjuvant. Methods Mol Biol (2016) 1403:269-84. doi: 10.1007/978-1-4939-3387-7_14

31. Jiang S, Lu L, Du L. Development of SARS vaccines and therapeutics is still needed. Future Virol (2013) 8:1-2. doi: 10.2217/fvl.12.126

32. World Health Organization. Draft landscape of COVID-19 candidate vaccines (2020). Available at: https://www.who.int/publications/m/item/draftlandscape-of-covid-19-candidate-vaccines (Accessed October 1, 2020).

33. Moderbacher CR, Ramirez SI, Dan JM, Grifoni A, Hastie KM, Weiskopf D, et al. Antigen-specific adaptive immunity to SARS-CoV-2 in acute COVID-19 and associations with age and disease severity. Cell (2020) 183:1-17. doi: $10.1016 /$ j.cell.2020.09.038

34. Iwasaki A, Yang Y. The potential danger of suboptimal antibody responses in COVID-19. Nat Rev Immunol (2020) 20:339-41. doi: 10.1038/s41577-0200321-6

35. Wang Q, Zhang L, Kuwahara K, Li L, Liu Z, Li T, et al. Immunodominant SARS Coronavirus Epitopes in Humans Elicited both Enhancing and Neutralizing Effects on Infection in Non-human Primates. ACS Infect Dis (2016) 2:361-76. doi: 10.1021/acsinfecdis.6b00006

36. Wan Y, Shang J, Sun S, Tai W, Chen J, Geng Q, et al. Molecular Mechanism for Antibody-Dependent Enhancement of Coronavirus Entry. J Virol (2020) 94:e02015-19. doi: 10.1128/jvi.02015-19

37. Yasui F, Kai C, Kitabatake M, Inoue S, Yoneda M, Yokochi S, et al. Prior immunization with severe acute respiratory syndrome (SARS)-associated coronavirus (SARS-CoV) nucleocapsid protein causes severe pneumonia in mice infected with SARS-CoV. J Immunol (2008) 181:6337-48, doi: 10.4049/ jimmunol.181.9.6337

38. Graham BS, Henderson GS, Tang YW, Lu X, Neuzil KM, Colley DG. Priming immunization determines $\mathrm{T}$ helper cytokine mRNA expression patterns in lungs of mice challenged with respiratory syncytial virus. J Immunol (1993) 151:2032-40.

39. Li X, Wang $\mathrm{X}$, Ito A. Tailoring inorganic nanoadjuvants towards nextgeneration vaccines. Chem Soc Rev (2018) 47:4954-80. doi: 10.1039/ c8cs00028j

40. Singh M. Recent Advances in Vaccine Adjuvants. Pharm Res (2002) 19:71528. doi: 10.1023/A:1016104910582

41. Sun B, Ji Z, Liao Y-P, Wang M, Wang X, Dong J, et al. Engineering an Effective Immune Adjuvant by Designed Control of Shape and Crystallinity of Aluminum Oxyhydroxide Nanoparticles. ACS Nano (2013) 7:10834-49. doi: $10.1021 / \mathrm{nn} 404211 \mathrm{j}$

42. Heaton PM. The Covid-19 Vaccine-Development Multiverse. N Engl J Med (2020). doi: 10.1056/NEJMe2025111

43. Bai S, Dong A. Effects of immobilization onto aluminum hydroxide particles on the thermally induced conformational behavior of three model proteins. Int J Biol Macromol (2009) 45:80-5. doi: 10.1016/ j.ijbiomac.2009.04.008

44. Ruwona TB, Xu H, Li X, Taylor AN, Shi YC, Cui Z. Toward understanding the mechanism underlying the strong adjuvant activity of aluminum salt nanoparticles. Vaccine (2016) 34:3059-67. doi: 10.1016/j.vaccine.2016.04.081

45. See RH, Zakhartchouk AN, Petric M, Lawrence DJ, Mok CP, Hogan RJ, et al. Comparative evaluation of two severe acute respiratory syndrome (SARS) vaccine candidates in mice challenged with SARS coronavirus. J Gen Virol (2006) 87:641-50. doi: 10.1099/vir.0.81579-0

46. Honda-Okubo Y, Barnard D, Ong CH, Peng B-H, Tseng C-TK, Petrovsky N. Severe Acute Respiratory Syndrome-Associated Coronavirus Vaccines Formulated with Delta Inulin Adjuvants Provide Enhanced Protection while Ameliorating Lung Eosinophilic Immunopathology. J Virol (2015) 89:2995-3007. doi: 10.1128/jvi.02980-14

47. Deming D, Sheahan T, Heise M, Yount B, Davis N, Sims A, et al. Vaccine Efficacy in Senescent Mice Challenged with Recombinant SARS-CoV Bearing Epidemic and Zoonotic Spike Variants. PLoS Med (2006) 3:e525. doi: 10.1371/ journal.pmed.0030525

48. Hotez PJ, Corry DB, Strych U, Bottazzi ME. COVID-19 vaccines: neutralizing antibodies and the alum advantage. Nat Rev Immunol (2020) 20:399-400. doi: 10.1038/s41577-020-0358-6

49. Kong SL, Chui P, Lim B, Salto-Tellez M. Elucidating the molecular physiopathology of acute respiratory distress syndrome in severe acute respiratory syndrome patients. Virus Res (2009) 145:260-9. doi: 10.1016/ j.virusres.2009.07.014

50. O'Hagan DT, Ott GS, De Gregorio E, Seubert A. The mechanism of action of MF59 - An innately attractive adjuvant formulation. Vaccine (2012) 30:43418. doi: 10.1016/j.vaccine.2011.09.061

51. Garcon N, Vaughn DW, Didierlaurent AM. Development and evaluation of AS03, an Adjuvant System containing alpha-tocopherol and squalene in an oil-in-water emulsion. Expert Rev Vaccines (2012) 11:349-66. doi: 10.1586/ erv.11.192

52. Morel S, Didierlaurent A, Bourguignon P, Delhaye S, Baras B, Jacob V, et al. Adjuvant System AS03 containing alpha-tocopherol modulates innate immune response and leads to improved adaptive immunity. Vaccine (2011) 29:2461-73. doi: 10.1016/j.vaccine.2011.01.011

53. Agrawal AS, Tao X, Algaissi A, Garron T, Narayanan K, Peng BH, et al. Immunization with inactivated Middle East Respiratory Syndrome coronavirus vaccine leads to lung immunopathology on challenge with live virus. Hum Vaccin Immunother (2016) 12:2351-6. doi: 10.1080/ 21645515.2016.1177688

54. Zhang N, Channappanavar R, Ma C, Wang L, Tang J, Garron T, et al. Identification of an ideal adjuvant for receptor-binding domain-based subunit vaccines against Middle East respiratory syndrome coronavirus. Cell Mol Immunol (2016) 13:180-90. doi: 10.1038/cmi.2015.03

55. Nyon MP, Du L, Tseng C-TK, Seid CA, Pollet J, Naceanceno KS, et al. Engineering a stable $\mathrm{CHO}$ cell line for the expression of a MERS-coronavirus vaccine antigen. Vaccine (2018) 36:1853-62. doi: 10.1016/j.vaccine. 2018.02.065 
56. Kong WP, Xu L, Stadler K, Ulmer JB, Abrignani S, Rappuoli R, et al. Modulation of the immune response to the severe acute respiratory syndrome spike glycoprotein by gene-based and inactivated virus immunization. J Virol (2005) 79:13915-23. doi: 10.1128/JVI.79.22.1391513923.2005

57. Tang J, Zhang N, Tao X, Zhao G, Guo Y, Tseng C-TK, et al. Optimization of antigen dose for a receptor-binding domain-based subunit vaccine against MERS coronavirus. Hum Vaccin Immunother (2015) 11:1244-50. doi: 10.1080/21645515.2015.1021527

58. Kim Y-S, Son A, Kim J, Kwon SB, Kim MH, Kim P, et al. Chaperna-Mediated Assembly of Ferritin-Based Middle East Respiratory Syndrome-Coronavirus Nanoparticles. Front Immunol (2018) 9:1093. doi: 10.3389/fimmu.2018.01093

59. Roberts A, Lamirande EW, Vogel L, Baras B, Goossens G, Knott I, et al. Immunogenicity and protective efficacy in mice and hamsters of a betapropiolactone inactivated whole virus SARS-CoV vaccine. Viral Immunol (2010) 23:509-19. doi: 10.1089/vim.2010.0028

60. Steinhagen F, Kinjo T, Bode C, Klinman DM. TLR-based immune adjuvants. Vaccine (2011) 29:3341-55. doi: 10.1016/j.vaccine.2010.08.002

61. Kaisho T, Akira S. Toll-like receptors as adjuvant receptors. Biochim Biophys Acta Mol Cell Res (2002) 1589:1-13. doi: 10.1016/S0167-4889(01)00182-3

62. Gai W, Zou W, Lei L, Luo J, Tu H, Zhang Y, et al. Effects of different immunization protocols and adjuvant on antibody responses to inactivated SARS-CoV vaccine. Viral Immunol (2008) 21:27-37. doi: 10.1089/ vim.2007.0079

63. Zhao K, Wang $\mathrm{H}, \mathrm{Wu} \mathrm{C}$. The immune responses of $\mathrm{HLA}-\mathrm{A}^{\star} 0201$ restricted SARS-CoV S peptide-specific CD8+ T cells are augmented in varying degrees by CpG ODN, PolyI:C and R848. Vaccine (2011) 29:6670-8. doi: 10.1016/ j.vaccine.2011.06.100

64. Channappanavar R, Fett C, Zhao J, Meyerholz DK, Perlman S. Virus-specific memory CD8 T cells provide substantial protection from lethal severe acute respiratory syndrome coronavirus infection. J Virol (2014) 88:11034-44. doi: 10.1128/JVI.01505-14

65. Weeratna RD, Brazolot Millan CL, McCluskie MJ, Davis HL. CpG ODN can re-direct the Th bias of established Th2 immune responses in adult and young mice. FEMS Immunol Med Microbiol (2001) 32:65-71. doi: 10.1111/j.1574695X.2001.tb00535.X

66. Lien SP, Shih YP, Chen HW, Tsai JP, Leng CH, Lin MH, et al. Identification of synthetic vaccine candidates against SARS $\mathrm{CoV}$ infection. Biochem Biophys Res Commun (2007) 358:716-21. doi: 10.1016/j.bbrc.2007.04.164

67. Liu S, Leng C, Lien S, Chi H, Huang C, Lin C, et al. Immunological characterizations of the nucleocapsid protein based SARS vaccine candidates. Vaccine (2006) 24:3100-8. doi: 10.1016/j.vaccine.2006.01.058

68. Cheng L, Zhang Z, Li G, Li F, Wang L, Zhang L, et al. Human innate responses and adjuvant activity of TLR ligands in vivo in mice reconstituted with a human immune system. Vaccine (2017) 35:6143-53. doi: 10.1016/ j.vaccine.2017.09.052

69. Gadd AJR, Castelletto V, Kabova E, Shankland K, Perrie Y, Hamley I, et al. High potency of lipid conjugated TLR7 agonist requires nanoparticulate or liposomal formulation. Eur J Pharm Sci (2018) 123:268-76. doi: 10.1016/ j.ejps.2018.07.048

70. Dowling DJ. Recent Advances in the Discovery and Delivery of TLR7/8 Agonists as Vaccine Adjuvants. Immunohorizons (2018) 2:185-97. doi: 10.4049/immunohorizons.1700063

71. Kwak HW, Park H-J, Ko HL, Park H, Cha MH, Lee S-M, et al. Cricket paralysis virus internal ribosome entry site-derived RNA promotes conventional vaccine efficacy by enhancing a balanced Th1/Th2 response. Vaccine (2019) 37:5191-202. doi: 10.1016/j.vaccine.2019.07.070

72. Lin LC, Huang CY, Yao BY, Lin JC, Agrawal A, Algaissi A, et al. Viromimetic STING Agonist-Loaded Hollow Polymeric Nanoparticles for Safe and Effective Vaccination against Middle East Respiratory Syndrome Coronavirus. Adv Funct Mater (2019) 29:1807616. doi: 10.1002/adfm.201807616
73. V'kovski P, Gultom M, Steiner S, Kelly J, Russeil J, Mangeat B, et al. Disparate temperature-dependent virus-host dynamics for SARS-CoV-2 and SARS$\mathrm{CoV}$ in the human respiratory epithelium. BioRxiv (2020). doi: 10.1101/ 2020.04.27.062315

74. Uematsu S, Fujimoto K, Jang MH, Yang BG, Jung YJ, Nishiyama M, et al. Regulation of humoral and cellular gut immunity by lamina propria dendritic cells expressing Toll-like receptor 5. Nat Immunol (2008) 9:769-76. doi: $10.1038 /$ ni. 1622

75. Madhun AS, Haaheim LR, Nostbakken JK, Ebensen T, Chichester J, Yusibov V, et al. Intranasal c-di-GMP-adjuvanted plant-derived H5 influenza vaccine induces multifunctional Th1 CD4+ cells and strong mucosal and systemic antibody responses in mice. Vaccine (2011) 29:4973-82. doi: 10.1016/ j.vaccine.2011.04.094

76. Wang J, Li P, Yu Y, Fu Y, Jiang H, Lu M, et al. Pulmonary surfactantbiomimetic nanoparticles potentiate heterosubtypic influenza immunity. Science (2020) 367:869. doi: 10.1126/science.aau0810

77. Xia Y, Wu J, Wei W, Du Y, Wan T, Ma X, et al. Exploiting the pliability and lateral mobility of Pickering emulsion for enhanced vaccination. Nat Mater (2018) 17:187-94. doi: 10.1038/nmat5057

78. Tao X, Garron T, Agrawal AS, Algaissi A, Peng BH, Wakamiya M, et al. Characterization and Demonstration of the Value of a Lethal Mouse Model of Middle East Respiratory Syndrome Coronavirus Infection and Disease. J Virol (2016) 90:57-67. doi: 10.1128/JVI.02009-15

79. Wang Y, Tai W, Yang J, Zhao G, Sun S, Tseng CK, et al. Receptor-binding domain of MERS-CoV with optimal immunogen dosage and immunization interval protects human transgenic mice from MERS-CoV infection. Hum Vaccin Immunother (2017) 13:1615-24. doi: 10.1080/21645515.2017. 1296994

80. Tai W, Zhao G, Sun S, Guo Y, Wang Y, Tao X, et al. A recombinant receptorbinding domain of MERS-CoV in trimeric form protects human dipeptidyl peptidase 4 (hDPP4) transgenic mice from MERS-CoV infection. Virology (2016) 499:375-82. doi: 10.1016/j.virol.2016.10.005

81. Peng S, Cao F, Xia Y, Gao XD, Dai L, Yan J, et al. Particulate Alum via Pickering Emulsion for an Enhanced COVID-19 Vaccine Adjuvant. Adv Mater (2020) 32:2004210. doi: 10.1002/adma.202004210

82. Jiang S, Bottazzi ME, Du L, Lustigman S, Tseng CT, Curti E, et al. Roadmap to developing a recombinant coronavirus $S$ protein receptor-binding domain vaccine for severe acute respiratory syndrome. Expert Rev Vaccines (2012) 11:1405-13. doi: 10.1586/erv.12.126

83. Sun B, Ji Z, Liao YP, Chang CH, Wang X, Ku J, et al. Enhanced Immune Adjuvant Activity of Aluminum Oxyhydroxide Nanorods through Cationic Surface Functionalization. ACS Appl Mater Interfaces (2017) 9:21697-705. doi: 10.1021/acsami.7b05817

84. Li X, Aldayel AM, Cui Z. Aluminum hydroxide nanoparticles show a stronger vaccine adjuvant activity than traditional aluminum hydroxide microparticles. J Controlled Release (2014) 173:148-57. doi: 10.1016/j.jconrel.2013.10.032

Conflict of Interest: WZ was employed by NCPC Genetech Biotechnology Co., Ltd. LS was employed by Shanghai Zerun Biotechnology Co., Ltd.

The remaining authors declare that the research was conducted in the absence of any commercial or financial relationships that could be construed as a potential conflict of interest.

Copyright (c) 2020 Liang, Zhu, Wang, Jing, Li, Xia, Sun, Yang, Zhang, Shi, Zeng and Sun. This is an open-access article distributed under the terms of the Creative Commons Attribution License (CC BY). The use, distribution or reproduction in other forums is permitted, provided the original author(s) and the copyright owner(s) are credited and that the original publication in this journal is cited, in accordance with accepted academic practice. No use, distribution or reproduction is permitted which does not comply with these terms. 